\title{
Gabapentin and pregabalin in the pain setting: All you need to know
}

\section{Sharon Rees}

\section{Abstract}

The last decade has seen a marked increase in the use of gabapentinoid drugs for pain management. This, in part, reflects the shift from some non-steroidal anti-inflammatory drugs (NSAIDs), as well as issues arising from the protracted use of opioids. More extensive use of gabapentin and pregabalin, has seen the clinical role widen to incorporate a range of unlicensed pain scenarios, as well as increased medicines' costs.

The evidence for efficacy in some pain conditions, namely postherpetic neuralgia and diabetic neuropathic pain, is stronger than for non-neuropathic pain conditions, such as fibromyalgia. Anxiolytic properties, as well as widespread availability, have encouraged recreational misuse, which is associated with doses outside the therapeutic range.

Safe use for neuropathic pain (central and peripheral), complex pain, migraine, and the evidence for some non-neuropathic pain conditions will be discussed, as well as the emerging abuse issues. Anti-convulsant interventions will not be covered in this article, nor will use in children.

Key words: Gabapentin; pregabalin; neuropathic pain; adjuvant pain drugs; misuse
$\mathrm{O}$ riginally licensed as anticonvulsants, the gabapentinoid drugs, namely gabapentin and pregabalin, have become popular agents in the pain setting. Known as adjuvant pain medications, because their primary class of action is not as analgesics, prescriptions for these drugs have increased exponentially in the UK, by $150 \%$ (gabapentin) and $350 \%$ (pregabalin) between 2011 and 2016 (Spence, 2013; Iverson, 2016).

Traditionally, the main use of gabapentinoids has been for the relief of neuropathic pain, and, in the context of licensed use, specifically peripheral neuropathic pain (gabapentin) and peripheral and central neuropathic pain (pregabalin) (Joint Formulary Committee, 2018). Gabapentin was licensed as an

Sharon Rees

Associate Professor Therapeutics and Prescribing,

London South Bank University

sharon.rees@isbu.ac.uk anti-epileptic in the UK in 1993, and pregabalin in 2004 (Morrison et al, 2017).

The gabapentinoids act by inhibiting calcium currents on central nervous system (CNS) presynaptic neurons, suppressing nerve signalling. While there is no proven direct effect on the inhibitory neurotransmitter GABA, there are putative effects on many neurotransmitter systems, including GABA and the monoamines (Eroglu et al, 2009) (Table 1). The ability to modulate pain pathways may be the reason why neuropathic pain responds to these drugs, while treatment with traditional analgesics has been less successful (Chen et al, 2004).

The explanation for the significant increase in prescribing for chronic pain conditions, and, in particular, the use of gabapentinoids, over the last decade, is unclear. Some increase is likely to be related to the search for alternatives to traditional pain relief options, given the safety issues associated with using many of the most common and popular analgesics, namely opioids, co-proxamol (now excluded) and drugs with analgesic activity, such as non-steroidal antiinflammatory drugs (NSAIDs). Furthermore, marketing claims in the 1990s, promoting gabapentinoid use for unapproved conditions, such as non-neuropathic pain, may well have perpetuated the expansion of prescription use (Steinman et al, 2006). The practice of off-label prescribing appears to have taken hold, despite acknowledged violations of legal marketing boundaries (Newman, 2010; Ghinea et al, 2015) and subsequent clarification of approved indications for use. All prescribers are able to prescribe outside the licensed indications for a given drug, but it is incumbent on the clinician to have first ensured that this decision meets certain criteria. These include acceptable efficacy, no licensed alternative that is suitable, and that the decision is in the patient's best interests (Medicines and Healthcare products Regulatory Agency (MHRA), 2009). The responsibility for any greater risks to the patient lies with the prescribing clinician and appropriate counselling relating to safe use must be in place (MHRA, 2009).

Cochrane reports by Wiffen et al (2017) and Moore et al (2009) supported benefits for gabapentin and pregabalin, respectively, for post-herpetic neuralgia and 


\begin{tabular}{|c|c|c|}
\hline Receptor/Target & Effect on pain & Reference \\
\hline $\begin{array}{l}\text { a2 } 11 \text { subunit on high voltage activated } \\
\text { calcium channel }\end{array}$ & Reduces pain signal transmission & $\begin{array}{l}\text { Gee et al (1996) } \\
\text { Eroglu et al (2009) }\end{array}$ \\
\hline Vallinoid receptor 1 (TrpV1) & Blocks sensory nerve pain transmission & Kim et al (2014) \\
\hline NMDA receptor & Inhibition of the NMDA receptor blocks glutamate function & $\begin{array}{l}\text { Hara and Sata } \\
(2007) \\
\text { Yang et al (2009) }\end{array}$ \\
\hline a2 adrenergic receptors & $\begin{array}{l}\text { Enhance descending pain inhibition } \\
\text { Anti-allodynic effects attributed to this }\end{array}$ & $\begin{array}{l}\text { Tanabe et al } \\
(2005)\end{array}$ \\
\hline $\begin{array}{l}\text { Decreased release norepinephrine, } \\
\text { glutamate, substance } P\end{array}$ & $\begin{array}{l}\text { Lower levels excitatory neurotransmitters means less pain } \\
\text { perception }\end{array}$ & $\begin{array}{l}\text { Stahl (2004) } \\
\text { Martinotti et al } \\
\text { (2013) }\end{array}$ \\
\hline $\begin{array}{l}\text { Glutamic acid decarboxylase (GAD) } \\
\text { (stimulates GABA) }\end{array}$ & By increasing levels, more GABA produced & Taylor (1997) \\
\hline
\end{tabular}

painful diabetic neuropathy. However, weaker evidence for other types of neuropathic pain, such as cancer nerve pain and complex regional pain syndrome was found (Wiffen et al, 2017). The mean number needed to harm $(\mathrm{NNH})$ for all cause neuropathic pain, based on at least one adverse event was 7.5 for gabapentin, at a daily dose of $>1200 \mathrm{mg}$, although the $\mathrm{NNH}$ for serious events was not calculated (Wiffen et al, 2017). Pregabalin data showed a NNH for $300 \mathrm{mg}$ at 6.6, representing at least one adverse event or serious adverse event (Moore et al, 2009).

\section{Mechanism of action}

Gabapentin and pregabalin are structurally related and appear to share the same mechanism(s) of action, but the full mechanism of action remains unclear. As the names suggest, these are analogues of the inhibitory neurotransmitter GABA, and although this was the rationale behind their development, they do not act on $\mathrm{GABA}_{\mathrm{A}}$ or $\mathrm{GABA}_{\mathrm{B}}$ receptors directly (Taylor et al, 1998). Central nervous system neurons transmit signals based on neurotransmitter types and levels at the synapse, and the degree of excitability of the nerve (propensity to propagate the signal). The extent of neurotransmitter availability relies on the influx of calcium ions, as this triggers neurotransmitter release. The calcium channel can be used as a switch. By modifying calcium flow, neurotransmitter disposal and the signal strength will increase or decrease.

Gabapentin and pregabalin both act to bind to a sub-unit on the voltage-gated calcium channels ( $a 2 \delta)$. This causes a narrowing of the channel, and ultimately decreases the amplitude of pain signals; therefore, less pain is perceived. Pregabalin binding has a stronger affinity for the channel, hence the higher potency (Jones and Sorkin, 1998) (Table 2). This suppression of neuron signalling is non-specific, exerting general effects on nociceptive pathways. It is thought that there are differences in the pain signals arising from damaged nerves, for example an up-regulation of the $a 2 \delta$ calcium channel subunit in damaged nerves (Alles and Smith, 2016), compared to the signals emitted from damaged tissues. Efficacy in neuropathic pain could relate to this mechanism of action (Chen et al, 2018). It is relevant that the non-specific effects may also manifest as neurotoxic events, such as sedation, cognitive dysfunction, respiratory depression and visual disturbances (electronic Medicines Compendium, 2017; 2018).

A further consequence of gabapentinoid administration is elevated central GABA levels, which is why these drugs are useful in seizure control (Treimann, 2001). A variety of interactions with GABA systems, and modulation of other pain targets are noted, although some are based on animal models and the full picture remains speculative. Therefore, by enhancing the inhibitory effects of GABA, less excitatory glutamate is functional and lower levels of monoamine neurotransmitters are released, all of which suppress pain signalling (Cunningham et al, 2004; Bauer et al, 2010; Cai et al, 2012).

\section{Pharmacokinetics and clinical profile}

The faster absorption of pregabalin allows a rapid onset of action (Guay, 2005). Gabapentin does not follow first order kinetics because its absorption systems are saturable. In practical terms, this means that a higher dose is linked to lower bioavailability. There is no relevant plasma protein binding for either drug, a feature helpful for minimising drug-drug interactions 


\begin{tabular}{|c|c|c|}
\hline Parameter & Gabapentin & Pregabalin \\
\hline $\begin{array}{l}\text { Indication for use } \\
\text { (pain related only) }\end{array}$ & $\begin{array}{l}\text { Peripheral neuropathic pain } \\
\text { Migraine prophylaxis }\end{array}$ & $\begin{array}{l}\text { Peripheral and central } \\
\text { neuropathic pain }\end{array}$ \\
\hline $\begin{array}{l}\text { Dose range (minimum level } \\
\text { efficacious for neuropathic pain) }\end{array}$ & $\begin{array}{l}1200-3600 \mathrm{mg} / \text { day } \\
\text { (Wiffen et al, 2017) }\end{array}$ & $\begin{array}{l}300-600 \mathrm{mg} / \mathrm{day} \\
\text { (Moore et al, 2009) }\end{array}$ \\
\hline Time to Cmax /bioavailability & $2-3$ hours $/ 60 \%$ & 1 hour $/>90 \%$ \\
\hline Potency & Less potent & 2.8-6 times more potent \\
\hline Half life & 5-7 hours & 6.3 hours \\
\hline Metabolism & none & none \\
\hline Excretion & Renal (unchanged drug) & Renal (unchanged drug) \\
\hline $\begin{array}{l}\text { Very common }(\geq 1 / 10) \text {, } \\
\text { or common adverse drug } \\
\text { reaction } \\
(\geq 1 / 100 \text { to }<1 / 10)\end{array}$ & $\begin{array}{l}\text { Dizziness, somnolence } \\
\text { and fatigue } \\
\text { Increased appetite } \\
\text { Peripheral oedema }\end{array}$ & $\begin{array}{l}\text { Dizziness and somnolence } \\
\text { Increased appetite } \\
\text { Peripheral oedema }\end{array}$ \\
\hline $\begin{array}{l}\text { Serious adverse drug reaction } \\
\text { (NOT exhaustive list) }\end{array}$ & $\begin{array}{l}\text { Pneumonia } \\
\text { Leucopenia } \\
\text { Psychiatric reactions } \\
\text { Pancreatitis } \\
\text { Rhabdomyolysis }\end{array}$ & $\begin{array}{l}\text { Psychiatric reactions } \\
\text { Convulsions } \\
\text { Congestive cardiac failure }\end{array}$ \\
\hline Drug-drug interactions & $\begin{array}{l}\text { CNS depressants, e.g. opiates } \\
\text { and benzodiazepines } \\
\text { (potentiation of effects) }\end{array}$ & $\begin{array}{l}\text { CNS depressants e.g. } \\
\text { opiates and benzodiazepines } \\
\text { (potentiation of effects) }\end{array}$ \\
\hline Drug-disease interactions & $\begin{array}{l}\text { Diabetes mellitus } \\
\text { Elderly } \\
\text { History psychotic illness } \\
\text { Mixed seizures }\end{array}$ & $\begin{array}{l}\text { Conditions that may precipitate } \\
\text { encephalopathy } \\
\text { Severe congestive cardiac failure }\end{array}$ \\
\hline Additional cautions & $\begin{array}{l}\text { High risk of respiratory depression } \\
\text { e.g. in elderly and those on CNS } \\
\text { depressants (see MHRA warning) }\end{array}$ & \\
\hline Withdrawal timeline & Over minimum one week & over minimum one week \\
\hline Cost (drug tariff price) * & $£ 3.24$ & $£ 64.40$ \\
\hline \multicolumn{3}{|c|}{$\begin{array}{l}\text { CNS - central nervous system } \\
{ }^{\star} \text { Based on highest dose for neuropathic pain for one month using the cheapest option } \\
\text { From: electronic Medicines Compendium (2017); Medicines and Healthcare products Regulatory Agency (2017); electronic Medicines } \\
\text { Compendium (2018); Joint Formulary Committee (2018); }\end{array}$} \\
\hline
\end{tabular}

and adverse drug reactions (Johannessen Landmark and Patsalos, 2010).

One of the major advantages of this drug class is that they are not metabolised in the liver (Patsalos, 2013). This removes one of the most frequent causes of drug-drug interactions, that of phase 1 metabolism changes effected by other drugs. However, the lack of biotransformation does mean that the majority of these drugs are excreted whole by the kidneys (>98\%) (Bockbrader et al, 2010). In situations where renal function is sufficiently compromised, the reduced clearance will mean less drug is eliminated and more whole drug will circulate for longer. This has implications for toxicity and the dose should be adjusted accordingly.

\section{Central neuropathic pain}

Central neuropathic pain can occur following CNS injury, with stroke being a common cause (Bowsher, 1996). It can be difficult to distinguish from peripheral pain, since the impact on peripheral structures, such as muscle denervation, spasticity and overuse of unaffected sites, can produce pain. Clearly, these can coexist, complicating the pain-generating diagnosis 
and management. Pregabalin is licensed for central neuropathic pain management and is used post-stroke, for multiple sclerosis and for pain associated with spinal cord injury (Watson and Sandroni, 2016).

Although unlicensed for central neuropathic pain, gabapentin is included in the National Institute for Health and Care Excellence (NICE) guidance, European Federation of Neurological Societies (EFNS) and the Canadian Pain Society recommendations for post-stroke central neuropathic pain (Attal et al, 2010; Moulin et al, 2014). The EFNS and the NICE guidelines for neuropathic pain do not distinguish between central and peripheral neuropathic pain (NICE, 2018a; Attal et al, 2010), hence both anticonvulsants appear in the guidelines.

A large systematic review conducted by Mulla et al (2015) suggested over-statement of many studies regarding the effect(s) of all interventions for central neuropathic pain, including for the anti-convulsants. Publication bias is also acknowledged by Finnerup et al (2015) regarding drugs used in neuropathic pain by up to $10 \%$. They report 'modest' efficacy for gabapentin and pregabalin, at a number needed to treat (NNT) of 7.2 (5.9-9.21) and 7.7 (6.5-9.4), respectively. In clinical terms, this means that for every 7-8 patients, one will experience $50 \%$ or more reduction in neuropathic pain, when compared to placebo.

\section{Complex pain}

In common with other chronic pain syndromes, neuropathic pain can involve central sensitisation (Woolf, 2011). This can lock someone into a 'pain loop' from which it can be hard to escape, making effective treatment problematic. For example, following some cases of nerve injury, complex regional pain syndrome (CRPS) can occur, although nerve damage is not always the cause (Rockett, 2014). This atypical and chronic reaction to injury is often disproportionate to the injury level and can be severe and intractable (Rockett, 2014). O'Connell et al's (2013) Cochrane review does not recommend a drug for neuropathic pain is used in CRPS, stating the current evidence for any effective intervention is of poor quality.

A common form of nerve injury is radiculopathy, a compression syndrome originating at the 'root' of the nerve, e.g sciatic nerve, producing radiating pain. The approach is for first line drug intervention with NSAIDs and/or opioids, but if pain remains uncontrolled, an agent for neuropathic pain can be considered (NICE, 2017a). The choice includes the gabapentinoids, but no one agent is recommended as superior, selection being made on the optimal agent for the individual.

Phantom limb pain is another example of complex and severe pain, which is suggested to have a neuropathic element (Wiffen et al, 2017). For such conditions, only some people respond to the gabapentinoid drugs, which is unsurprising due to the

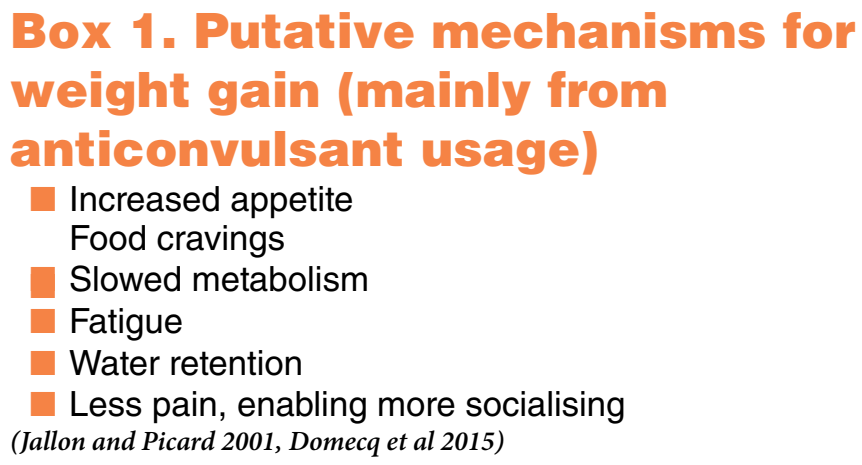

complexity of the pain pathways and the individual responses to chronic pain. The evidence remains conflicted (Alviar et al, 2011; O’Connell et al, 2013) and a personalised approach to complex pain may be necessary.

\section{Painful diabetic neuropathy}

The strongest evidence for use is for neuropathic pain, of which painful diabetic neuropathy is a common cause (Dieleman et al, 2008). The NICE Clinical Knowledge Summaries (CKS) do not differentiate between a number of different drug classes as firstline interventions, allowing the clinician to select the most appropriate for the individual (NICE, 2015). However, the gabapentinoids are popular options (Rajan et al, 2014). The mean NNTis reported as 5.9 for gabapentin (Wiffen et al, 2017), and 5 for pregabalin (Moore et al, 2009), compared to placebo. Advantages include safe use with other medications, a particular benefit for the diabetic population given the frequency of polypharmacy. They are generally well-tolerated, although weight gain is a common side effect and can be an issue, with particular health implications in the diabetic population (Box 1).

\section{Post-herpetic neuralgia}

Damage from the varicella zoster virus represents one of the most painful nerve syndromes (Johnson, 2007), and is associated with burning, stabbing pain, sensory deficits, sleep disturbance and depression (Beal et al, 2012). There is a well-defined role for using the gabapentinoids for pain relief, with a mean NNT of 6.7 for gabapentin (Wiffen et al, 2017) and 3.9 for pregabalin (Moore et al, 2009). If the pain is uncontrolled with simple analgesics and practical steps such as loose clothing, NICE recommend pharmacological intervention as per neuropathic pain. No single drug on the neuropathic pain pathway is recommended over another (NICE, 2017b).

\section{Migraine}

Despite 'migraine prophylaxis' being an indication for gabapentin, this is an unlicensed use for the drug. 


Box 2. Safe use of gabapentinoids
Careful titration: start low and go slow
Discount if not effective (usually allow at least 8 weeks
for effect)
If effective, titrate down to minimal effective level
Counselling for benefits versus side effects and drug driving
Warn about dependence and clarify distinction with addiction
Check history of substance abuse
Care if being co-prescribed with opiates
Do not stop suddenly
If unlicensed use, ensure patient gives informed consent.
From: National Institute for Health and Care Excellence (NICE) (2015); NICE (2018a);
PrescQuipp (2016); Public Health England (2014)

Pregabalin is neither indicated, nor licensed, for use in this setting. As a cause of complex and sometimes intractable pain, migraine was one of the conditions for which gabapentin 'expanded' into trials and off-label use (Di-Trapani et al, 2000; Spira et al, 2003). However, a Cochrane review by Linde et al (2013) found that it was not an effective intervention to prevent migraine and recommended that it should not be routinely prescribed. Accordingly, the CKS pathway does not include gabapentin as a drug option (NICE, 2018b).

\section{Fibromyalgia}

The chronic pain associated with fibromyalgia is notoriously complex and multi-dimensional, but it is not classified as a neuropathic condition. In Canada and the US, pregabalin is licensed for fibromyalgia, but this is not the case for Europe. Derry et al (2016) reported that pregabalin can work for a sub-set (10\%) of fibromyalgia patients to improve pain. In those who do not respond with pain relief, there may be other benefits, such as improved quality of life and function (Derry et al, 2016). The evidence for gabapentin was weaker, and Cooper et al's (2017) Cochrane review was inconclusive regarding a beneficial effect. More recent approaches to fibromyalgia include pain management programmes, which aim to place the patient at the centre in controlling their own pain (Wilkinson and Whiteman, 2017).

\section{Acute and post-operative pain}

Uses for the gabapentinoids in acute pain have emerged. There is most evidence for its use in post-operative pain. One of the areas in which prescribing has increased is following spinal surgery. Other uses have been primarily where acute pain may have an atypical or possibly neuropathic dimension, such as with burn injury. While the current literature supporting this is mostly case studies, future research may better inform clinical practice.

After surgery there is an up-regulation of calcium channels on neurons, because of the increase in cell signal traffic (Bauer et al, 2010). This positions the gabapentinoids as a theoretically useful approach in post-surgical pain, with particular advantages for neurosurgeries, as the $\alpha 2 \delta 1$ calcium channel subunit is predominantly expressed in the dorsal horn (Bauer et al, 2010). However, the effects on acute pain are controversial, as the majority of evidence is for chronic and neuropathic pain. A Cochrane review found a positive effect of gabapentin on acute pain, but an NNT of 11 . While this showed that a single dose of $250 \mathrm{mg}$ could reduce acute pain, it was inferior to standard NSAIDs and paracetamol interventions (Straube et al, 2010).

Other studies have shown that there is an opioidsparing effect when using the gabapentinoids in the post-operative situation, with related advantages in reducing opioid adverse reactions, such as nausea and vomiting. This comes at the expense of the gabapentinoid adverse drug reaction profile that includes sedation and visual disturbances (Tiippana et al, 2007). It is noteworthy that no evidence supports use after surgery, to achieve prevention of chronic post-operative pain (Martinez et al, 2017). Public Health England (PHE) state that prescribing for non-neuropathic pain is not evidence-based (PHE, 2014). While acute pain represents an interesting application for these drugs, the evidence-base is mainly experimental and such prescribing is likely to be by specialist teams only.

\section{Discontinuation}

Drugs acting on CNS signalling systems exert complex effects, which are not fully understood, but it is known that certain drugs acting on these systems must be initiated and withdrawn with care (Parsons, 2018). GABA is the main fast inhibitory neurotransmitter in the CNS and is formed from glutamate, which is the main fast excitatory neurotransmitter (Huang and Thathiah, 2015). This relationship allows tightly coupled control of neural signalling, which also involves a multitude of other neurotransmitters and receptors.

As with all psychotropic drugs, neurotransmitter function(s) and signalling systems in central nervous system neuronal pathways become altered possibly because of changes to receptor expression (Cai et al, 2012). Accordingly, the regimen for use typically involves gradual adjustment to the dose, and careful titration to effective levels. If stopped abruptly, the CNS does not have the chance to re-adjust and this can lead to disruption of function around the new 'set points'. The scenarios studied for withdrawal relate to seizure control, as opposed to neuropathic pain (UK Medicines Information, 2015), making the effects of adjustment within the pain dose ranges theoretical.

Regarding GABA concentration changes, cessation can have features similar to withdrawal from benzodiazepines and alcohol, as both of these also alter 
GABA function (Lobo and Harris, 2008). Withdrawal symptoms can be unpleasant, namely insomnia, irritability, headaches, gastrointestinal upset and can result in tachycardia, seizures and psychiatric reactions, such as suicidal ideation (Mersfelder and Nichols, 2016; Parsons, 2018). Occurrence of these symptoms does not represent 'addiction' to the drug, although this is a common misconception. Addiction is defined by compulsive drug-seeking behaviour and continued use, despite recognition of harm (American Society of Addiction Medicine (ASAM), 2011). It is important that this distinction is made clear to patients, in order to support safe use and concordance (Box 2).

The recommended tapering procedure is to reduce the dose over a minimum of 1 week (eMC, 2017; 2018), although the British National Formulary (BNF) only states this for pregabalin (Joint Formulary Committee, 2018). However, when used in the pain setting, more gradual discontinuation is helpful to monitor the effect(s) of stoppage on the background condition (PHE, 2014). PHE recommend:

Pregabalin: reduce the daily dose at a maximum of 50-100 mg/week

Gabapentin: reduce the daily dose at a maximum rate of $300 \mathrm{mg}$ every 4 days.

If one or the other drug does not work, only partially work, or is not tolerated, it is possible to switch from one to the other. The cross-tapering protocol is approached in one of two ways. The first is to stop, using the formal discontinuation stages over at least 1 week (or longer, see above) and then to start to titrate up the alternative drug. This may allow breakthrough pain. The second is to start titrating in the other drug before full discontinuation until pain relief is established (PrescQipp, 2016).

\section{Misuse}

Greater prescription use and wider acknowledgement of gabapentinoid properties have fuelled a significant black market, abetted by online purchasing, e.g. using online pharmacies (Schifano et al, 2011). The current status as a 'prescription only medicine' and 'uncontrolled' drug group, which has not traditionally had an 'abuse' reputation, means that the gabapentinoids are excluded from the standard drug monitoring procedures. This has enabled illicit purchasing and abuse, under the radar of the authorities, both of which are particularly prevalent in the prison population and in addiction clinics (Recoppa et al, 2004; Smith et al, 2012; Baird et al 2014).

In the UK, this misuse has led to the Advisory Council for the Misuse of Drugs (ACMD) investigating the clinical and abuse roles of gabapentin and pregabalin, with a view to re-classification as controlled drugs. Growing evidence of harm has been reported from the increased number of deaths citing these drugs ( 1 and 4 in 2009 to 26 and 38 in 2014, respectively (Office for National Statistics, 2016), as well as rising emergency department admissions (Millar et al, 2013). The latest information in Spring 2018 is agreement from the Government to accept the ACMD advice to re-classify pregabalin as a class $\mathrm{C}$ drug, after analysis from the public consultation has been completed (Iacobucci, 2017).

The characteristics of the gabapentinoids that encourage misuse include the ability to mix with many other medical and recreational drugs, such as alcohol, opioids, cannabis, selective serotonin reuptake inhibitors and amphetamines (Smith et al, 2012; Smith et al, 2016). When mixed, the potential for harm is significantly increased, causing sedation, respiratory failure and death (Lyndon et al, 2017). Both gabapentin and pregabalin can produce relaxation and elevated mood and, if crushed and inhaled nasally, can produce a 'high' similar to cocaine (Schifano et al, 2011).

Furthermore, both may be used to potentiate the effects of methadone (Baird et al, 2014) and are used as cutting agents for heroin (Smith et al 2012).

Pregabalin was made a scheduled drug in the US in 2005 (schedule V), reflecting its higher abuse potential. This is probably related to its greater potency and there being a faster onset of action (Häkkinen et al 2014). There are calls for gabapentin to be 'scheduled' in the US too, particularly following a systematic review by Smith et al (2016) looking into gabapentin abuse in the US and Europe. Findings included a general population misuse rate of $1 \%$, but this increased up to $65 \%$ for people with other prescriptions. The review found a strong relationship between opioid use (Wilens et al, 2015) and alcohol use (Häkkinen et al, 2014; Schifano et al, 2011) and gabapentin. Certainly, in the $\mathrm{UK}$, it is already recommended that these drugs are only prescribed to people with a history of substance abuse, after the benefits and risks have been carefully considered (PHE, 2014). For this group, the preferred first line agent for neuropathic pain is amitriptyline (PrescQipp, 2016).

Perhaps ironically, pregabalin is also used to help manage alcohol, benzodiazepine and narcotic withdrawal (Oulis et al, 2012; Freynhagen et al, 2016), because a number of its effects relate to suppression of neuronal excitability. The very properties that make it suitable for a range of psychiatric and neurological conditions, also make it subject to abuse. It should be noted that the doses applied for medical use are effective within the therapeutic range, permitting intervention with a low risk of harm or abuse. Indeed, within dose range, and as monotherapy, these drugs are considered safe.

\section{Conclusion}

There is strong evidence to support the use of the gabapentinoids for two common neuropathic pain conditions: painful diabetic neuropathy and post- 
herpetic neuralgia. Clinical efficacy is less certain for other types of neuropathic pain and caution should be exercised, even for other causes of pain either known, or perceived to be, neuropathic. There is a lack of compelling evidence for all other uses and the local pain pathway and up-to-date guidelines should be consulted, to ensure prescribing conforms to current best practice.

In view of the unlicensed status for other pain uses, and the potential for harm, clinicians should be fully aware of the relevant accountabilities in such scenarios. Exemplary counselling and support during use should help minimise safety issues. The growing misuse of this drug class is likely to focus clinical usage in the near future and it is clear that those with a history of recreational misuse (of any drug class) should avoid these drugs. Approaches to chronic pain management are slowly changing and the trend towards viewing complex pain though a non-pharmacological lens is growing, particularly as the harmful aspects of drug interventions are exposed.

Alles SR, Smith PA. The anti-allodynic gabapentinoids: myths, paradoxes, and acute effects. Neuroscientist. 2016. https://doi org/10.1177/1073858416628793.

Alviar MJ, Hale T, Dungca M. Pharmacologic interventions for treating phantom limb pain. Cochrane Database Syst Rev. 2011;(12):CD006380. https://doi.org/10.1002/14651858. CD006380.pub2

American Society of Addiction Medicine. Public Policy Statement: Short Definition of Addiction. 2011. www.asam.org/docs/ default-source/public-policy-statements/1definition_of_ addiction_short_4-11.pdf?sfvrsn=6e36cc2_0. (accessed 11 April 2018)

Attal N, Cruccu G, Baron R et al. EFNS guidelines on the pharmacological treatment of neuropathic pain: 2010 revision. Eur J Neurol. 2010;17(9):1113-e88. https://doi.org/10.1111/ j.1468-1331.2010.02999.x

Baird CRW, Fox P, Colvin LA. Gabapentinoid abuse in order to potentiate the effect of methadone: a survey among substance misusers. Eur Addict Res. 2014;20(3):115-118. https://doi. org $/ 10.1159 / 000355268$

Bauer CS, Tran-Van-Minh A, Kadurin I, Dolphin AC. A new look at calcium channel $\alpha 2 \delta$ subunits. Curr Opin Neurobiol. 2010;20(5):563-571.https://doi.org/10.1016/j.conb.2010.05.007

Beal B, Moeller-Bertram T, Schilling JM, Wallace MS. Gabapentin for once-daily treatment of post-herpetic neuralgia: a review. Clin Interv Aging. 2012;7:249-255.

Joint Formulary Committee. British National Formulary. London: BMJ Group and Pharmaceutical Press: 2018

Bockbrader HN, Wesche D, Miller R, Chapel S, Janiczek $\mathrm{N}$, Burger P. A comparison of the pharmacokinetics and pharmacodynamics of pregabalin and gabapentin. Clin Pharmacokinet. 2010;49(10):661-669. https://doi. org/10.2165/11536200-000000000-00000

Bowsher D. Central pain: clinical and physiological characteristics. J Neurol Neurosurg Psychiatry. 1996;61(1):62-69. https://doi. org/10.1136/jnnp.61.1.62 Medline

Cai K, Nanga RPR, Lamprou L et al. The impact of gabapentin administration on brain GABA and glutamate concentrations: a $7 \mathrm{~T}^{1} \mathrm{H}-\mathrm{MRS}$ study. Neuropsychopharmacology. 2012;37(13):2764-2771. https://doi.org/10.1038/npp.2012.142
Chen J, Li L, Chen SR et al. The $\alpha 2 \delta$-1-NMDA receptor complex is critically involved in neuropathic pain development and gabapentin therapeutic actions. Cell Rep 27;22(9):2307-2321 . https://doi.org/10.1016/j.celrep.2018.02.021

Chen H, Lamer TJ, Rho RH, Marshall KA, Sitzman BT, Ghazi SM, Brewer RP. Contemporary management of neuropathic pain for the primary care physician. Mayo Clin Proc. 2004;79(12):15331545. https://doi.org/10.4065/79.12.1533

Cooper TE, Derry S, Wiffen PJ, Moore RA. Gabapentin for fibromyalgia pain in adults. Cochrane Database Syst Rev. 2017 ;1(1):CD012188. https://doi.org/10.1002/14651858.CD012188. pub2

Cunningham MO, Woodhall GL, Thompson SE, Dooley DJ, Jones RSG. Dual effects of gabapentin and pregabalin on glutamate release at rat entorhinal synapses in vitro. Eur J Neurosci. 2004;20(6):1566-1576. https://doi.org/10.1111/j.14609568.2004.03625.x

Derry S, Cording M, Wiffen PJ, Law S, Phillips T, Moore RA. Pregabalin for pain in fibromyalgia in adults. Cochrane Database Syst Rev. 2016;9(9):CD011790. https://doi. org/10.1002/14651858.CD011790.pub2

Dieleman JP, Kerklaan J, Huygen FJPM, Bouma PAD, Sturkenboom MCJM. Incidence rates and treatment of neuropathic pain conditions in the general population. Pain. 2008;137(3):681-688. https://doi.org/10.1016/j. pain.2008.03.002

Di Trapani G, Mei D, Marra C, Mazza S, Capuano A. Gabapentin in the prophylaxis of migraine: a double-blind randomized placebo-controlled study. Clin Ter. 2000;151(3):145-148

Domecq JP, Prutsky G, Leppin A et al. Clinical review: Drugs commonly associated with weight change: a systematic review and meta-analysis. J Clin Endocrinol Metab. 2015;100(2):36370. https://doi.org/10.1210/jc.2014-3421

electronic Medicines Compendium. Gabapentin 600mg. 2017. https://www.medicines.org.uk/emc/ product/5002\#UNDESIRABLE_EFFECTS (accessed 19 June 2018)

electronic Medicines Compendium. Pregabalin 300mg. 2018. https://www.medicines.org.uk/emc/ product/7444\#UNDESIRABLE_EFFECTS (accessed 19 June 2018)

Eroglu C, Allen NJ, Susman MW et al. Gabapentin receptor alpha2delta-1 is a neuronal thrombospondin receptor responsible for excitatory CNS synaptogenesis. Cell. 2009;139(2):380-92. https://doi.org/10.1016/j.cell.2009.09.025

Finnerup NB, Attal N, Haroutounian S et al. Pharmacotherapy for neuropathic pain in adults: a systematic review and meta-analysis. Lancet Neurol. 2015;14(2):162-73. https://doi. org/10.1016/S1474-4422(14)70251-0

Freynhagen R, Backonja M, Schug $S$ et al. Pregabalin for the Treatment of Drug and Alcohol Withdrawal Symptoms: A Comprehensive Review. CNS Drugs. 2016;30(12):1191-1200. https://doi.org/10.1007/s40263-016-0390-z

Gee NS, Brown JP, Dissanayake VUK, Offord J, Thurlow R, Woodruff GN. The novel anticonvulsant drug, gabapentin (Neurontin), binds to the alpha2delta subunit of a calcium channel. J Biol Chem. 1996;271(10):5768-5776. https://doi. org $/ 10.1074 /$ jbc. 271.10 .5768

Ghinea N, Lipworth W, Kerridge I. Evidence, regulation and 'rational' prescribing: the case of gabapentin for neuropathic pain. J Eval Clin Pract. 2015;21(1):28-33. https://doi. org/10.1111/jep. 12223

Guay DRP. Pregabalin in neuropathic pain: A more "pharmaceutically elegant" gabapentin? Am J Geriatr Pharmacother. 2005;3(4):274-287. https://doi.org/10.1016/j. amjopharm.2005.12.008 
Guglielmo R, Martinotti G, Clerici M, Janiri L. Pregabalin for alcohol dependence: a critical review of the literature. Adv Ther. 2012;29(11):947-957. https://doi.org/10.1007/s12325012-0061-5

Häkkinen M, Vuori E, Kalso E, Gergov M, Ojanperä I. Profiles of pregabalin and gabapentin abuse by postmortem toxicology. Forensic Sci Int. 2014;241:1-6. doi:10.1016/j. forsciint.2014.04.028

Hara K, Sata T. Inhibitory effect of gabapentin on N-methyl$\mathrm{d}$-aspartate receptors expressed in Xenopus oocytes. Acta Anaesthesiol Scand. 2007;51(1):122-128. https://doi. org/10.1111/j.1399-6576.2006.01183.x

Iacobucci G. UK government to reclassify pregabalin and gabapentin after rise in deaths. BMJ. 2017 Sep 25;358:j4441. https://doi.org/10.1136/bmj.j4441

Linde M, Mulleners WM, Chronicle EP, McCrory DC. Gabapentin or pregabalin for the prophylaxis of episodic migraine in adults. Cochrane Database Syst Rev. 2013;(6):CD010609. doi:10.1002/14651858.CD010609

Lobo IA, Harris RA. GABAA receptors and alcohol. Pharmacol Biochem Behav. 2008;90(1):90-94. https://doi.org/10.1016/j. pbb.2008.03.006

Lyndon A, Audrey S, Wells C et al. Risk to heroin users of polydrug use of pregabalin or gabapentin. Addiction. 2017;112(9):1580-1589. https://doi.org/10.1111/add.13843

Iversen L. Re: Pregabalin and gabapentin advice. 2016. https:// www.gov.uk/government/uploads/system/uploads/attachment_ data/file/491854/ACMD_Advice_-_Pregabalin_and_ gabapentin.pdf. (accessed 7 June 2018)

Jallon P, Picard F. Bodyweight gain and anticonvulsants: a comparative review. Drug Saf. 2001;24(13):969-78

Johannessen Landmark C, Patsalos PN. Drug interactions involving the new second- and third-generation antiepileptic drugs. Expert Rev Neurother. 2010 Jan;10(1):119-40. https:// doi.org/10.1586/ern.09.136

Johnson RW. Zoster-associated pain: what is known, who is at risk and how can it be managed? Herpes. 2007;14 Suppl 2:30-4

Jones D, Sorkin L. Systemic gabapentin and 3-isobutylaminobutyric acid block secondary hyperalgesia. Brain Res. 1998 Nov 9;810(1-2):93-9

Kim YS, Chu Y, Han L et al. Central terminal sensitization of TRPV1 by descending serotonergic facilitation modulates chronic pain. Neuron. $2014 \mathrm{Feb}$ 19;81(4):873-887. https://doi. org/10.1016/j.neuron.2013.12.011

Martinez V, Pichard X, Fletcher D. Perioperative pregabalin administration does not prevent chronic postoperative pain: systematic review with a meta-analysis of randomized trials. Pain. 2017;158(5):775-783.https://doi.org/10.1097/j. pain. 000000000000838

Martinotti G, Lupi M, Sarchione F et al. The potential of pregabalin in neurology, psychiatry and addiction: a qualitative overview. Curr Pharm Des. 2013;19(35):6367-74

Medicines and Healthcare Products Regulatory Agency. Off-label or unlicensed use of medicines: prescribers' responsibilities. 2009. https://www.gov.uk/drug-safety-update/off-label-orunlicensed-use-of-medicines-prescribers-responsibilities (accessed 19 June 2018)

Medicines and Healthcare Products Regulatory Agency. Gabapentin (Neurontin): risk of severe respiratory depression. 2017. https://www.gov.uk/drug-safety-update/gabapentinneurontin-risk-of-severe-respiratory-depression (accessed 19 June 2018)

Mersfelder TL, Nichols WH. Gabapentin: abuse, dependence and withdrawal. Ann Pharmacother. 2016;50(8):692. https://doi. org/10.1177/1060028016655426

\section{Key Points}

There is satisfactory evidence that gabapentin and pregabalin can be used as effective interventions for certain types of neuropathic pain, mainly painful diabetic neuropathy and post-herpetic neuralgia

Due consideration must be given to prescribing gabapentin or pregabalin for off-label uses

A detailed understanding of initiating, using, and stopping these drugs is required for safe practice

The propensity for misuse must form part of the prescribing decision-making process, as well as patient counselling

- The UK status of pregabalin is likely to change to a controlled drug in the near future

\section{CPD reflective questions}

What are the properties of gabapentin and pregabalin which make them useful for treating neuropathic pain?

What are the properties of gabapentin and pregabalin which make them attractive for misuse?

What areas of safety netting are going to be important to consider when prescribing these drugs?

Why has it become popular to prescribe outside of the licensed indications for use?

What will you consider discussing with patients before initiating these drugs?

Why is it important to avoid abrupt withdrawal?

Millar J, Sadasivan S, Weatherup N, Lutton S. Lyrica nightsrecreational pregabalin abuse in an urban emergency department. Emerg Med J. 2013;30:874

Moore RA, Straube S, Wiffen PJ, Derry S, McQuay HJ. Pregabalin for acute and chronic pain in adults. Cochrane Database Syst Rev. 2009 Jul 8;(3):CD007076. https://doi. org/10.1002/14651858.CD007076.pub2

Morrison EE, Sandilands EA, Webb DJ. Gabapentin and pregabalin: do the benefits outweigh the harms?J R Coll Physicians Edinb. 2017 Dec;47(4):310-313. https://doi. org/10.4997/JRCPE.2017.402

Moulin D, Boulanger A, Clark AJ et al; Canadian Pain Society. Pharmacological management of chronic neuropathic pain: revised consensus statement from the Canadian Pain Society. Pain Res Manag. 2014 Nov-Dec;19(6):328-35

Mulla SM, Wang L, Khokhar R et al. Management of central poststroke pain: systematic review of randomized controlled trials. Stroke. 2015;46(10):2853-60. https://doi.org/10.1161/ STROKEAHA.115.010259

Newman M. Bitter pills for drug companies. BMJ 2010; 341. https://doi.org/10.1136/bmj.c5095

PrescQipp. Neuropathic pain: Pregabalin and gabapentin prescribing. 2016. https://www.prescqipp.info/care-homescovert-admin/send/80-pregabalin-in-neuropathic-pain/2463bulletin-119-neuropathic-pain (accessed 11 June 2018)

National Institute for Health and Care Excellence. Clinical Knowledge Summaries. Neuropathic Pain-drug treatment. 2015. https://cks.nice.org.uk/neuropathic-pain-drugtreatment\#!scenario (accessed 11 June 2018) 
National Institute for Health and Care Excellence. Clinical Knowledge Summaries. Sciatica (lumbar radiculopathy). 2017a. https://cks.nice.org.uk/sciatica-lumbar-radiculopathy\#!scenario (accessed 11 June 2018)

National Institute for Health and Care Excellence. Clinical Knowledge Summaries. Post-herpetic neuralgia. 2017b. https:// cks.nice.org.uk/post-herpetic-neuralgia\#!scenariorecommenda tion (accessed 11 June 2018)

National Institute for Health and Care Excellence. Clinical guideline CG173 Neuropathic Pain Pharmacological Management-Full Guideline. 2018a. http:// guidance.nice.org. uk/CG173/Guidance/pdf/English (accessed 11 June 2018)

National Institute for Health and Care Excellence. Clinical Knowledge Summaries. Migraine. 2018b. https://cks.nice.org uk/migraine\#!scenario (accessed 11 June 2018)

O'Connell NE, Wand BM, McAuley J, Marston L, Moseley G. Interventions for treating pain and disability in adults with complex regional pain syndrome- an overview of systematic reviews. Cochrane Database Syst Rev. 2013 Apr 30;(4):CD009416. https://doi.org/10.1002/14651858.CD009416. pub2

Office for National Statistics. Deaths related to drug poisoning in England and Wales: 2016 registrations. https:// www.ons.gov.uk/peoplepopulationandcommunity/ birthsdeathsandmarriages/deaths/bulletins/deathsrelatedtodru gpoisoninginenglandandwales/2016registrations\#people-aged40-to-49-years-have-the-highest-rate-of-drug-misuse-deaths (accessed 11 June 2018)

Oulis P, Konstantakopoulos G. Efficacy and safety of pregabalin in the treatment of alcohol and benzodiazepine dependence. Expert Opin Investig Drugs. 2012 Jul;21(7):1019-29. https:// doi.org/10.1517/13543784.2012.685651

Parsons G. Guide to the management of gabapentinoid misuse. Prescriber. 2018; 29:25-30

Patsalos PN. Drug interactions with the newer antiepileptic drugs (AEDs)-part 1: pharmacokinetic and pharmacodynamic interactions between AEDs. Clin Pharmacokinet. 2013 Nov;52(11):927-66. https://doi.org/10.1007/s40262-0130087-0

Public Health England. Advice for prescribers on the risk of the misuse of pregabalin and gabapentin. https://assets.publishing. service.gov.uk/government/uploads/system/uploads/ attachment_data/file/385791/PHE-NHS_England_pregabalin_ and_gabapentin_advice_Dec_2014.pdf (accessed 11 June 2018)

Rajan RS, de Gray L, George E. Painful diabetic neuropathy. Continuing Education in Anaesthesia Critical Care and Pain. 2014; 14(5):230-235

Reccoppa L, Malcolm R, Ware M. Gabapentin abuse in inmates with prior history of cocaine dependence. Am J Addict. 2004 May-;13(3):321-3. https://doi.org/10.1080/10550490490460300

Rockett M. (2014) Diagnosis, mechanisms and treatment of complex regional pain syndrome. Curr Opin Anaesthesiol. 2014;27(5):494-500. https://doi.org/10.1097/ ACO.0000000000000114

Schifano F, D'Offizi S, Piccione $\mathrm{M}$ et al. Is there a recreational misuse potential for pregabalin? Analysis of anecdotal online reports in comparison with related gabapentin and clonazepam data. Psychother Psychosom. 2011;80(2):118-22. https://doi. org $/ 10.1159 / 000321079$

Smith BH, Higgins C, Baldacchino A, Kidd B, Bannister J. Substance misuse of gabapentin. Br J Gen Pract. 2012;62(601):406-7. https://doi.org/10.3399/bjgp12X653516

Smith RV, Havens JR, Walsh SL. Gabapentin misuse, abuse and diversion: a systematic review. Addiction. 2016;111(7):1160-74. https://doi.org/10.1111/add.13324
Smith RV, Lofwall MR, Havens JR. Abuse and diversion of gabapentin among nonmedical prescription opioid users in Appalachian Kentucky. Am J Psychiatry. 2015;172(5): 487-8. https://doi.org/10.1176/appi.ajp.2014.14101272

Spence D. Bad medicine: gabapentin and pregabalin. BMJ. 2013;347:f6747. https://doi.org/10.1136/bmj.f6747

Spira PJ, Beran RG; Australian Gabapentin Chronic Daily Headache Group. Gabapentin in the prophylaxis of chronic daily headache: a randomized, placebo-controlled study. Neurology. 2003;61(12):1753-9

Stahl SM. Anticonvulsants as anxiolytics, part 2: pregabalin and gabapentin as alpha(2)delta ligands at voltage-gated calcium channels.J Clin Psychiatry. 2004;65(4):460-1

Steinman MA, Bero LA, Chren MM, Landefeld CS. Narrative review: the promotion of gabapentin: an analysis of internal industry documents. Ann Intern Med. 2006;145(4):284-93

Straube S, Derry S, Moore RA, Wiffen PJ, McQuay HJ. Single dose oral gabapentin for established acute postoperative pain in adults. Cochrane Database Syst Rev. 2010;(5):CD008183. https://doi.org/ 10.1002/14651858.CD008183.pub2

Tanabe M, Takasu K, Kasuya N, Shimizu S, Honda M, Ono H. Role of descending noradrenergic system and spinal alpha2adrenergic receptors in the effects of gabapentin on thermal and mechanical nociception after partial nerve injury in the mouse. Br J Pharmacol. 2005;144(5):703-14

Taylor CP. Mechanisms of action of gabapentin. Rev Neurol (Paris). 1997;153 Suppl 1:S39-45

Taylor CP, Gee NS, Su TZ et al. A summary of mechanistic hypotheses of gabapentin pharmacology. Epilepsy Res. 1998;29(3):233-49.

Tiippana EM, Hamunen K, Kontinen VK, Kalso E. Do surgical patients benefit from perioperative gabapentin/pregabalin? A systematic review of efficacy and safety. Anesth Analg. 2007;104(6):1545-56

Treiman DM. GABAergic mechanisms in epilepsy. Epilepsia. 2001;42(Suppl 3):8-12

UK Medicines Information. How do you switch between pregabalin and gabapentin for neuropathic pain, and vice versa? https://www.evidence.nhs. uk/h?q=\%22How + do + you + s witch+between+pregabalin+and+gabapentin+for+neuropathic +pain\% 2C+and+vice+versa\%22. (accessed 11 June 2018)

Watson JC, Sandroni P. Central neuropathic pain syndromes. Mayo Clin Proc. 2016;91(3):372-85. https://doi.org/10.1016/j. mayocp.2016.01.017

Wiffen PJ, Derry S, Bell RF, Rice ASC, Tölle T, Phillips T, Moore R.Gabapentin for chronic neuropathic pain in adults. Cochrane Database Syst Rev. 2017;6:CD007938. https://doi. org/10.1002/14651858.CD007938.pub4

Wilens T, Zulauf C, Ryland D, Carrellas N, Catalina-Wellington I. Prescription medication misuse among opioid dependent patients seeking inpatient detoxification. Am J Addict. 2015;24(2):173-7. https://doi.org/10.1111/ajad.12159

Wilkinson P, Whiteman R. Pain management programmes, BJA Education. 2017;17(1):10-15. https://doi.org/10.1093/bjaed/ mkw027

Woolf CJ. Central sensitization: implications for the diagnosis and treatment of pain. Pain. 2011;152(3 Suppl):S2-15. https://doi. org/ 10.1016/j.pain.2010.09.030

Yang RH, Wang WT, Chen JY, Xie RG, Hu SJ. Gabapentin selectively reduces persistent sodium current in injured type-A dorsal root ganglion neurons. Pain. 2009;143(1-2):48-55. https://doi.org/10.1016/j.pain.2009.01.020

Huang Y, Thathiah A. Regulation of neuronal communication by G protein-coupled receptors. FEBS Lett. 2015;589(14):1607-19. https://doi.org/ 10.1016/j.febslet.2015.05.007 